\title{
開胸にて摘出した義歯食道異物症例
}

$\begin{array}{lrrr}\text { 秋定 } & \text { 健, 吉弘 剛, 林 玻 巳 } \\ \text { 河合 晃 充, 東川 康彦, 折田 } & \text { 洋 造 }\end{array}$

\section{A Case of the Removal of an Esophageal Foreign Body (Dental Prosthesis) by Thoracotomy}

\author{
Takeshi Akisada, M.D., Tsuyoshi Yoshihiro, M.D., Takumi Hayashi, M.D., \\ Akimitsu Kawai, M.D., Yasuhiko Higashikawa, M.D., and Yozo Orita, M.D. \\ Department of Otolaryngology, Kawasaki Medical School, Okayama
}

A case of the removal of an esophageal foreign body (dental prosthesis) by thoracotomy was reported. The patient was a 63-year-old male who had complained of odynophagia after swallowing a dental prosthesis by mistake. Chest X-ray examination showed a foreign body having four sharp clasps. Emergency direct esophagoscopy was carried out, but the foreign body could not be removed due to the probable depression of the clasps in the esophageal membrane. Therefore, thoracotomy was performed under general anesthesia. Opening the mediastinum, there was a bloody serous exudate. The esophageal wall was continuously incised, and a part of the dental prosthesis was cut off with a pair of pliers. The remainder of the foreign body was easily removed by esophagoscopy. Thoracic drainage and chemotherapy were continued, and esophagography was carried out two weeks after the operation. The patient was discharged without complications.

\section{Key words : 義歯食道異物, 開胸, 縦隔洞炎}

\section{I .はじめに}

食道異物症例において，義歯やPTPで時に 食道穿孔や縦隔洞炎，大血管損傷などの合併症 とともに，頸部外切開例や開胸手術例について も報告されている。今回われわれは, 食道義歯 異物で食道鏡下の摘出困難のため，開胸摘出し た症例を経験したので, 若干の文献的考察を加 えて報告する。

\section{II . 症例 \\ 患 者：63歳, 男性}

川崎医科大学耳鼻咽喉科学教室

別刷請求： T701-01 岡山県倉敷市松島577 川崎医科大学耳鼻咽喉科 秋定 健 投稿受付：1993年 1 月14日
主 訴：義歯誤嚥，獣下困難

家族歴：特記すべきことなし

既往歷：進行性球麻痺（第 4 期梅毒） 45 歳 現病歴: 平成 2 年 10 月 2 日, 昼食時からソー メンを 2,3 本ずつしか食べられないなどの嚥 下困難状態に家人が気付き，夕食時には義歯が ないことに本人が気付くも放置していた。翌日 も食事摂取不能にて近医受診し，X 線撮影にて 食道義歯異物と診断され，他院にて内視鏡的摘 出を試みるも，摘出不能にて同日当院救急部受 診後当科紹介となる。

初診時現症：意識は清明だが時折コミュニ ケーション不能を認め, 舌萎縮と軽度の構音障 害を認めた。口腔内には異物を認めなかった。 血圧は158/90 とやや高く, 脈拍は $78 / \mathrm{min} て ゙$, 体 温は $37.3^{\circ} \mathrm{C}$ 軽度の発熱を認めた。 
検査所見：一般血液，尿検査では白血球数が 10,100 と増加し，Wa 氏が RPR 法で陽性以外 には異常を認めなかった(表 1 )。胸部 X 線撮影 (正面)で第 1 胸椎から第 3 胸椎にかけてクラス プを持つ義歯陰影を認め, 側面写真からも第 1 狭窄部から第 2 狭窄部にかけての食道異物と確 認された（図 1 )。

経 過: 他院での内視鏡的摘出が困難であっ たことから，クラスプの食道壁への陥入が予想 されたが，まず全身麻酔下に硬性食道鏡を施行 した。上門歯列から $17 \mathrm{~cm}$ 付近で義歯異物を確

表 1 入院時検查所見 (白血球の増加を認める)

\begin{tabular}{llll}
\hline WBC & $10,100(/ \mu 1) \uparrow$ & $\mathrm{Na}$ & $14(\mathrm{mEq} / \mathrm{l})$ \\
$\mathrm{RBC}$ & $438\left(\times 10^{4} / \mu 1\right)$ & $\mathrm{K}$ & $3.7(\mathrm{mEq} / \mathrm{l})$ \\
$\mathrm{Hb}$ & $13.9(\mathrm{~g} / \mathrm{dl})$ & $\mathrm{PH}$ & 7.430 \\
$\mathrm{Ht}$ & $40.1(\%)$ & $\mathrm{PCO}_{2}$ & $34.8(\mathrm{mmHg})$ \\
$\mathrm{SP}$ & $7.8(\mathrm{~g} / \mathrm{dl})$ & $\mathrm{PO}_{2}$ & $88(\mathrm{mmHg})$ \\
$\mathrm{BS}$ & $123(\mathrm{mg} / \mathrm{dl})$ & $\mathrm{BE}$ & $10.1(\mathrm{mEq} / \mathrm{l})$ \\
$\mathrm{GPT}$ GOT & $26(\mathrm{I} . \mathrm{U} / \mathrm{l})$ & 出血時間 1 分30秒 \\
BUN & $16.5(\mathrm{mg} / \mathrm{d} 1)$ & Wa氏 $: \mathrm{RPR}$ 法 陽性 \\
Amy & $238(\mathrm{I} . \mathrm{U} / \mathrm{l})$ & &
\end{tabular}

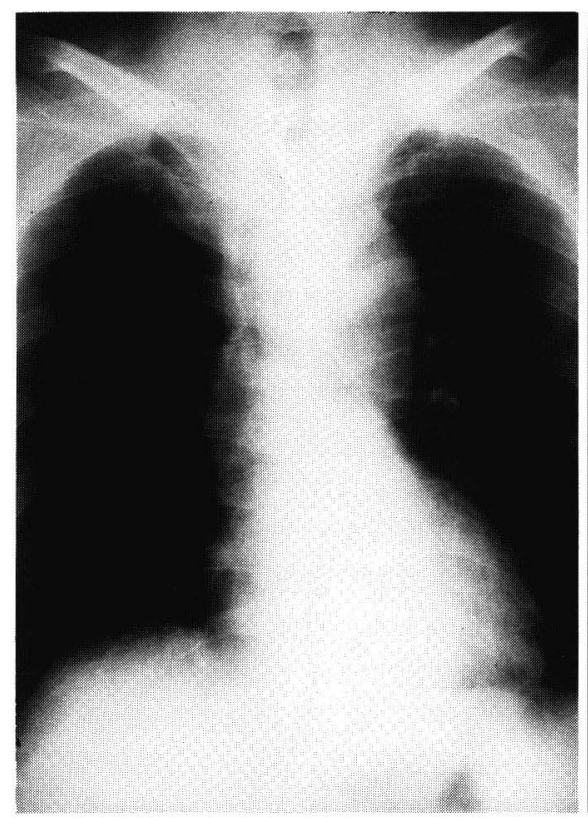

a. 正面像
認し，上方のクラスプを鉗子にて把持し摘出を 試みたが，固定しており不能にて，下方のクラ スプが食道粘膜に陥入していると考えられた。 Foley $の$ balloon catheter $や$ Fogarty $の$ balloon catheter を義歯上端から約 $7 \sim 8 \mathrm{~cm}$ 挿入 し，下方のクラスプ部の食道を拡張させるよう に試みたが摘出不能であった。

摘出操作で深夜に及んだため, ICUにて全身 麻酔を続行し, 翌朝胸部外科に開胸摘出を依頼 した。右側開胸で緹隔を切開すると, 軽度の血 性滲出液を認め, 縦隔洞炎の存在を疑わせた。 食道を䋛切開すると義歯下端のクラスプを触診 でき,食道壁に陥入していることを確認した(図 2)。

ニッパ (絞断器) にてクラスプの一端を切断 すると義歯の一部も同時に摘出できた。それ以 上の操作は困難にて, 再び食道鏡を口側より挿 入し，上方のクラスプを把持して牽引すると容 易に摘出できた（図 3 )。

食道粘膜の裂傷は軽度で穿孔は認めなかつ た。食道粘膜を縫合し縦隔と胸腔内にドレーン 挿入し手術を終了した。

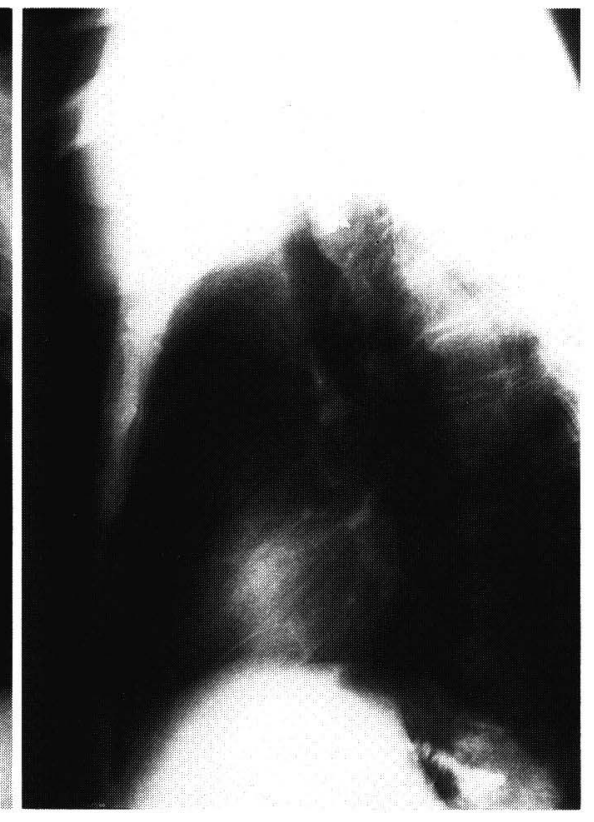

b. 側面像

図 1 入院時胸部 $\mathrm{X}$ 線撮影 
開胸時所見

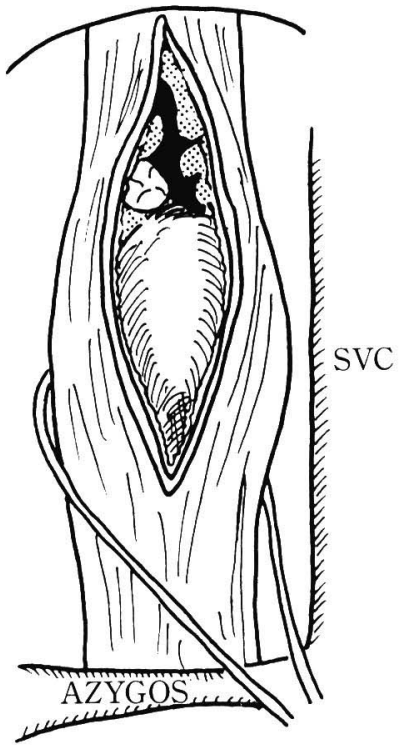

図 2 開胸手術所見

縦隔洞炎を疑わす血性滲出液を認め, 義歯下端が触 診可能であった。

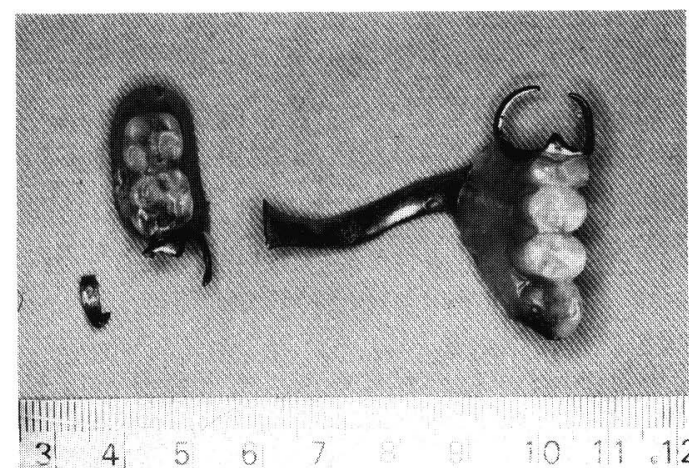

図 3 摘出義歯異物

術後経過は良好で, 胸部 X 線撮影でも縦隔洞 炎や肺炎は認めず (図 4)，術後11日目にドレー ンを拔去した。さらに食道造影を施行し狭窄や 漏洩像を認めないため(図 5 ), 経口攝取を開始 し11月 8 日に退院となった。

\section{III. 考 按}

食道異物の種類は魚骨，貨幣，玩具類，食片，

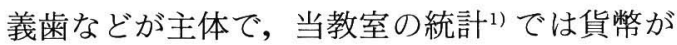

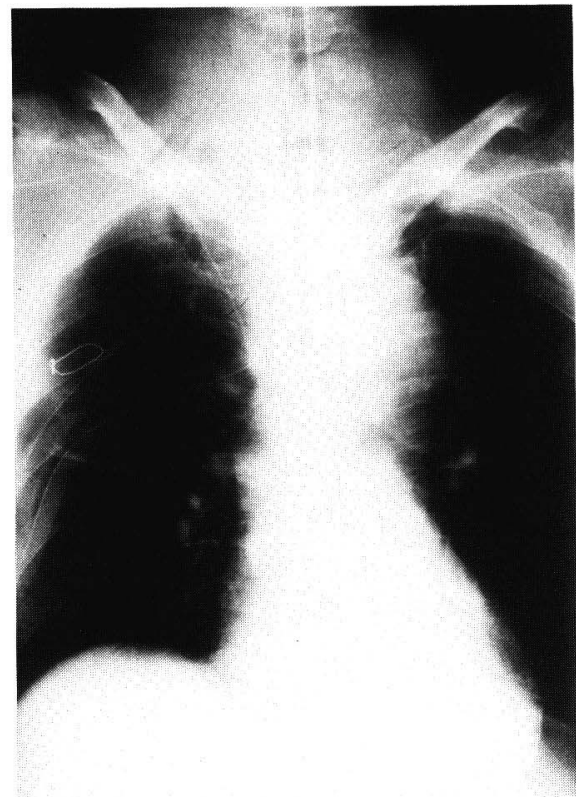

図 4 術後胸部 X 線撮影

異常陰影は認めない。

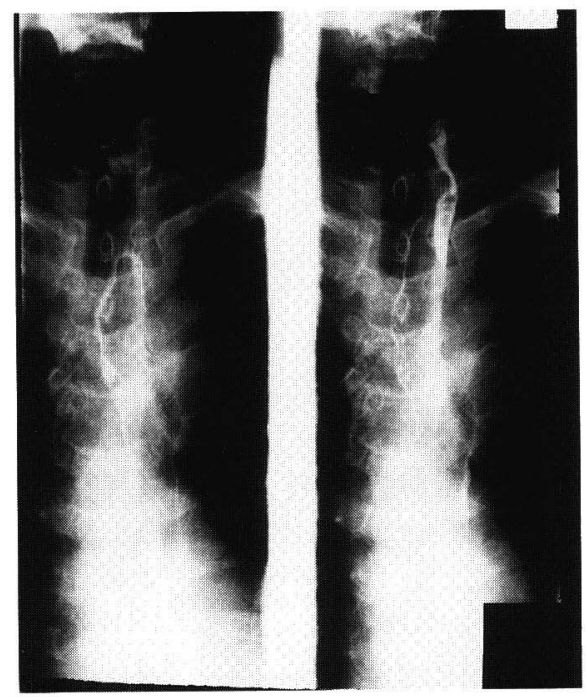

図 5 食道造影検査

狭窄や漏洩像は認めない。

61\%を占めている。また最近は PTP が増加し て問題となっている。義歯異物は食道異物のな かで Nandi ら ${ }^{2)}$ の報告では2394例中16例と少 ないが，本邦の報告3)では約 $5 \%$ 前後と考えら 
れ，やはり増加傾向と，若年層への波及が報告 されている。当教室においても PTP, 義歯の増 加は顕著である。食道異物全体の介在部位は第 1 狭窄部が圧倒的に多いが, 義歯, 食片は第 1 狭窄部，第 2 狭窄部が同じ割合で多いと報告さ れている4)。

山川 ${ }^{5}$ は, 食道異物症になり得る原因を 5 つ に大別しているが，義歯の場合は異物と知らな いで飲み込むか，睡眠中，無意識または反射運 動で䛊嘸することが多い。また䛊嚥時は嚥下痛 を訴え，炎症を併発するため，自然痛も起こる。 痛みは往久背部に放散すると報告されている が，今回の症例は第 4 期梅毒による進行性球麻 痺のため, 誤嬩時の状態およびその後の症状が 特殊で, コミュニケーションも取りにくいため, やや診断が遅れたと思われる。

食道異物のなかで義歯異物は最も摘出困難な 異物の 1 つであり，鋭利なクラスプを持つ有鈎 義歯において，その摘出法や多くの合併症が報 告されている。阿部ら ${ }^{6)}$ はろう義歯模型作製の 有用性について報告している。柴田ら7) は有鈎 義歯異物の摘出法について，全身麻酔にて十分 な筋弛緩を得て，できるだけ大きな径の管を使 用し，術前に義歯の形，大きさ，鈎の数，方向 などを確認し，方向によっては回転したりいっ たん押し込んだりすることの重要性，また場合 によってはへラや食道拡張期，力フ付管の使用 の有用性について報告している。

その他義歯以外では，鈍的異物の摘出目的で Bigler $^{8)}$ や Nixon ${ }^{9)}$ は Foley $の$ balloon catheterを使用し，Nixon ${ }^{9)}$ は Foley の balloon catheter が異物部を通過しにくい場合は Swan-ganz の catheter などの使用についても 報告しており，今回の症例では Fogartyの catheter も試みた。

食道ファイバーの使用については，内科医が 主に使用していると思われるが，下部食道異物 や PTP 異物や硬性鏡不能例などでは有用で, 局麻下でも苦痛が少ない，視野が良いなどの長 所があるが，義歯に関してはファイバーでは扱 いにくい第 1 狭窄部に多いことと，異物自体が 大きいことから食道ファイバーは適さないと思 われる。

食道異物における最大の合併症は，食道穿孔
に伴う縦隔洞炎や，縦隔膿瘍，膿胸，さらには 大血管損傷などである。食道穿孔の原因につい ては医原性が最も多いが, Foster ら ${ }^{10)}$ は42例の 食道穿孔中 2 例が異物であったとし，Keszler ら ${ }^{11)}$ は108例中義歯を含む異物に関連したもの が59例とし, Michel ら ${ }^{12)}$ は85例中 9 例, Bladergroen ら ${ }^{13)}$ は127例中14\%が異物によると報告 しており，報告により差が認められるが，治療 開始または手術時期において24時間を境界とし て死亡率や生存率に有意差を認めている。

異物による食道穿孔について本邦では PTP

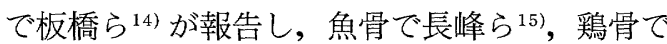
宗ら ${ }^{16)}$, チェーンで中川ら ${ }^{17)}$, カーテンレールで 斉田ら ${ }^{18)}$ が報告している。義歯異物では，内視 鏡下の摘出による食道穿孔を斉藤ら ${ }^{19)}$ が報告 しており，異物が食道壁に刺入していて内視鏡 的摘出が困難であったり，摘出過程で食道を損 傷する怖れのある場合や，すでに穿孔している 場合は時期を失わずに手術的に摘出すべきであ るとしている。

今回の症例は，食道穿孔に到る前に摘出不能 と考え開胸手術を施行しているが，すでに縦隔 洞炎を起こしていたことからも開胸の判断は的 確であったと考えている。依田 ${ }^{20)} も$ 同椂な症例 を経験し報告しているように，胸部外科手術お よび術後管理の進歩は著しいと思われ，食道鏡 摘出が不能と思われた場合には，いたずらに無 益な操作を加えず，頸部であれば頸部外切開， 胸部であれば積極的に開胸異物摘出に踏み切る ベきだと思われる。

食道異物による大血管系の合併症について は, 行木ら ${ }^{21)}$ は義歯による大動脈出血死例を報 告し, Carter ら ${ }^{22)}$ は24例の大動脈食道瘻中 1 例 は魚骨異物と報告し，Bozer ら ${ }^{23)}$ は魚骨異物に よる化膿性心外膜炎を報告している。稀ではあ るがこれらの合併症も起こり得ることを熟知し て扔くことも重要と思われる。

\section{IV.まと め}

義歯食道異物で食道鏡下の摘出困難のため, 開胸摘出した症例を経験したので若干の文献的 考察を加えて報告した。鋭利なクラスプを持っ た義歯では，食道穿孔など合併症を起こしやす いため，食道鏡摘出が困難な症例では躊躇せず 
に，胸部外科に開胸摘出を依頼するべきと思わ れる。

本論文の要旨は, 第17回日本耳鼻咽喉科学会中国 地方部会 (1991年 6 月 9 日, 米子市) において口演 した。

\section{文献}

1) 半田 徹, 折田洋造, 山本英一・他: 当教室開 設以来の気道 - 食道異物症例の統計. 川崎医学 会誌, $12 ： 349-354,1986$.

2) Nandi, C., and Ong, G.B. : Foreign body in the oesophagus: Review of 2394 cases. Br. J. Surg., $65: 5-9,1978$.

3 ）兵 行和: 気道・食道異物症の診断. 気道・食 道異物症, 臨床の実際, pp.43-78, 篠原出版, 東 京, 1983 .

4）佐野光仁：気道・食道異物症の統計。気道・食 道異物症, 臨床の実際, pp.19-41, 篠原出版, 東 京, 1983.

5 ）山川強四郎：異物の変遷.耳鼻， $2 ： 181-185$, 1955.

6 ）阿部 隆, 佐藤護人, 金子康治 - 他：義歯食道 異物摘出のためのろう義歯模型の作成。耳喉, $52: 967-971,1980$

7）柴田浩一，武田 修：有鈎義歯異物の摘出法に ついて.耳鼻, 21：508-510, 1975.

8 ) Bigler, F.C. : The use of a Foley catheter for removal of blunt foreign bodies from the esophagus. J. Thorac. Cardiovasc. Surg., $51: 759-760,1965$.

9 ) Nixon, G.W. : Foley catheter method of esophageal foreign body removal : Extension of applications. A.J.R., 132 : 441-442, 1979.

10) Foster, J.H., Jolly, P.C., Sawyers, J.I., et al. : Esophageal perforation: Diagnosis and treatment. Ann. Surg., 161: 701-709, 1965.

11) Keszler, P., and Buzna, E.: Surgical and conservative management of esophageal per- foration. Chest, $80: 158-162,1981$.

12) Michel, L., Grillo, H.C., and Malt, R.A.: Operative and nonoperative management of esophageal perforations. Ann. Surg., 194 : 57-63, 1981.

13) Bladergroen, M.R., Lowe, J.E., and Postlethwait, R.W.: Diagnosis and recommended management of esophageal perforation and rupture. Ann. Thorac. Surg., 42:235-239, 1986.

14）板橋敏之, 阿保七三郎, 工藤 保 - 他: 薬剤包 装 P.T.P. 食道異物による食道穿孔の一治験例. 秋田県医師会雑誌，38：124-127, 1986.

15）長峰健二，杉町圭蔵，小柳信洋・他：魚骨によ る食道穿孔の 1 治験例. 外科, $45 ： 985-987$, 1983.

16）宗弘，松尾信昭，野津史博・他：鷄骨に上 る食道穿孔の 1 治験例. 日消外会誌，21： 2292-2295, 1988.

17）中川雅文，松田史明，萩原秀夫・他：穿孔をき たした食道金属異物症例。耳鼻臨床，83： 939-943, 1990.

18）斉田晴仁, 調所廣之, 岡本和人・他：カーテン レールにより食道穿孔を生じた食道異物 1 症 例. 日気食会報, $40 ： 344-349,1989$ 。

19）斉藤寛文, 宮脇富士夫, 井出博文 - 他：義歯誤 嶼による食道穿孔の 1 治験例。外科診療， 31 ： 1079-1083, 1989.

20）依田美千穂：開胸手術により摘出した食道異物 (義歯) 症例.耳鼻, 19：390-395, 1973.

21）行木英生, 大塚 護, 原口茂徳 - 他：義歯誤嚥 による大動脈出血死例. 歯界展望， $49 ： 85-89$, 1977.

22) Carter, R., Mulder, G.A., Snyder, E.N., Jr., et al. : Aortoesophageal fistula. Am. J. Surg., 136:26-30, 1978.

23) Bozer, A.Y., Saylam, A., and Ersoy, U. : Purulent pericarditis due to perforation of esophagus with foreign body. J. Thorac. Cardiovasc. Surg., 67: 590-592, 1974. 